\title{
Why Did Young Families Lose So Much Wealth During the Crisis? The Role of Homeownership
}

\author{
William R. Emmons and Bryan J. Noeth
}

\begin{abstract}
The authors use the Federal Reserve's Survey of Consumer Finances to document a boom in home ownership and mortgage borrowing among young families in the years leading up to the recent financial crisis. Many young families lost more of their wealth during the downturn than middle-aged and older families. The authors find that about three-quarters of the decline in the average young family's wealth between 2007 and 2010 was due to its exposure to residential real estate. For middle-aged and older families, housing losses contributed about 53 percent and 40 percent of the total decline in wealth, respectively. Regression evidence suggests that young families' wealth, on average, was unusually highly concentrated in housing and these families' debt burdens were extremely high at the peak of the boom. (JEL D14, D31)
\end{abstract}

Federal Reserve Bank of St. Louis Review, January/February 2013, 95(1), pp. 1-26.

$\mathbf{R}$ ecently released data from the Federal Reserve's Survey of Consumer Finances (SCF) reveal that many young families suffered proportionately larger financial losses during the housing market downturn and accompanying recession than did middle-aged and older families. The average level of wealth in 2010 for young families (i.e., headed by someone younger than 40 years of age) declined by 43.8 percent, or $\$ 68,070$, from the average level in 2007.1,2 Meanwhile, the average level of wealth for middle-aged families (i.e., headed by someone between 40 and 61 years of age) declined by only 17.4 percent; levels for older families (i.e., headed by someone 62 years of age or older) declined by just 10.3 percent.

What accounts for these differences in loss of family wealth? Were there warning signs in the balance sheets of young families before the crash that indicated this group was particularly vulnerable to a collapse of the housing market or some other asset category? Do the financial setbacks suffered by many younger families in recent years represent a break from previous trends in wealth accumulation at different stages across the life cycle or a continuation of a longterm trend?

William R. Emmons is an assistant vice president and Bryan J. Noeth is a policy analyst at the Federal Reserve Bank in St. Louis. This work is part of the Household Financial Stability initiative at the Federal Reserve Bank of St. Louis (www.stlouisfed.org/hfs).

( ) 2013, The Federal Reserve Bank of St. Louis. The views expressed in this article are those of the author(s) and do not necessarily reflect the views of the Federal Reserve System, the Board of Governors, or the regional Federal Reserve Banks. Articles may be reprinted, reproduced, published, distributed, displayed, and transmitted in their entirety if copyright notice, author name(s), and full citation are included. Abstracts, synopses, and other derivative works may be made only with prior written permission of the Federal Reserve Bank of St. Louis. 


\section{Emmons and Noeth}

We document a boom and bust in homeownership and mortgage borrowing among young families that even exceeded the substantial aggregate boom and bust. Other asset and liability categories changed little among most young families.

We provide evidence that a large increase in exposure to residential real estate made many young homeowners quite vulnerable to the housing market crash and ensuing recession. We show that mortgage debt played (and will continue to play) two somewhat opposing roles in the boom and bust. On the one hand, a large increase in the amount of mortgage debt on the balance sheets of young families during the housing boom facilitated their rapid buildup of real estate exposures, paving the way for leveraged wealth destruction when the housing bubble burst. On the other hand, significant deleveraging during the bust-through voluntary paydowns of mortgage principal, negotiated principal reductions, short sales, and mortgage defaults-served as a balance-sheet buffer, or safety valve. This is because any decrease in a family's liabilities in excess of any associated loss of assets increases its net worth, by accounting definition. Of course, short sales and mortgage default come with a heavy cost in the form of damaged creditworthiness; but any reduction in negative homeowner's equity moves a family's net worth in a positive direction. $\underline{3}$

This article examines age-specific trends in family balance sheets and wealth between 1989 and 2010 using eight regular waves of the Federal Reserve's triennial SCF plus the 2007-09 panel dataset. .4 We rely primarily on data from the Federal Reserve's SCF, supplementing these rich cross-sectional financial snapshots of the population with other data sources. In addition to the age dimension of homeownership and mortgage borrowing, we also disaggregate the survey data to highlight the role of educational attainment and racial and ethnic identity in determining which young families were most affected by the surges and subsequent declines in homeownership, house prices, and mortgage borrowing. By exploiting the survey's family-level detail in a multiple-regression framework and controlling for a variety of factors, we confirm that the homeownership rate among young families was elevated at the peak of the housing boom (2004-07) relative to the rate that would have been expected.

Was it apparent before the downturn that young homeowners had risky levels of debt? Although the average mortgage loan-to-home value (LTV) ratios for young homeowners in 2004 and 2007 changed little from previous years, broader measures of leverage or debt burden, such as the total debt-to-total assets (DTA) ratio and the total debt-to-family income (DTI) ratio, departed notably from historical norms during the mid-2000s. Post-crash evidence (2007-09) confirms that debt burden measures were significant predictors of financial distress and wealth losses. Hence, balance-sheet data available before the crash revealed that younger families were dangerously exposed to the effects of a severe housing downturn. The ensuing loss of wealth continued a two-decade trend of younger families' wealth failing to keep pace with the wealth of their middle-aged and older counterparts.

We first document wealth and income trends by age group between 1989 and 2010. The next section examines homeownership and borrowing trends. This examination is followed by a detailed analysis of the race or ethnicity and educational-attainment dimensions of young families, further illuminating the largest shifts in homeownership and borrowing behavior over time. We then report the results of regression analyses of the pre-crash buildup of real estate holdings and mortgage debt as well as post-crash delinquency rates. 


\section{The Federal Reserve's Survey of Consumer Finances}

The Survey of Consumer Finances (SCF) is a triennial cross-sectional survey of several thousand families. In its current form, it has been conducted eight times, beginning in 1989, with the most recent survey in 2010. The SCF is the only survey conducted over an extended period of time in the United States that provides comprehensive data for a representative sample of U.S. families on the distribution of assets and debts, along with related economic information and other data items necessary for analyzing the financial behavior of all families. The Federal Reserve makes family-level data from the survey available to the public free of charge with about a two-year lag. Two panel studies for two-date periods have been conducted for 1983-89 and 2007-09. In this article, we use the cross-sectional and the 2007-09 panel data.

The SCF is conducted using a two-part sample design. First, there is an area probability sample, in which a random selection of families across the nation is interviewed. In addition, there is a list sample, which oversamples wealthy families, as inferred from Internal Revenue Service data. Adjustments are made after the data have been gathered to restore the correct sample proportions to the respondents along a number of important dimensions.

Recent SCF sample sizes have been increased, but they remain small for performing detailed examinations-particularly of the undersampled groups who are not wealthy, such as young, minority, and less-educated families. Sample sizes in the last three waves of the SCF were 4,519 (in 2004), 4,421 (in 2007), and 6,492 (in 2010).

Participation in the survey is voluntary and all responses remain strictly confidential. In an effort to protect the confidentiality of even the wealthiest respondents, some responses in the public data are altered to make it impossible to identify individual families. Geographic detail is not included in the public data in an additional effort to maintain confidentiality.

\section{NET WORTH AND INCOME TRENDS BY AGE GROUP}

The shocks to the balance sheets of U.S. families between 2007 and 2010 were the worst in the 21-year history of the SCF in its current form (see the boxed insert). Declines in net worth spread across virtually every segment of the population. Nonetheless, younger families suffered some of the largest percentage wealth losses. This section provides evidence that residential real estate was a major culprit in wealth declines between 2007 and 2010 among many younger families.

\section{Net Worth and Income: Means and Medians}

The mean percentage decline in net worth between 2007 and 2010 was 15.2 percent for all families. (See Emmons and Noeth, 2012b, for tables with detailed breakdowns of mean and median family net worth and income by age group between 1989 and 2010.) Older families (headed by someone aged 62 or older) lost an average of 10.3 percent, middle-aged families (headed by someone aged 40 to 61) lost an average of 17.4 percent, while younger families (headed by someone younger than 40 years) lost 43.9 percent. $\frac{5}{\text { Th }}$ The wealth losses suffered by younger families were so severe that, on average, their net worth in 2010 was significantly lower than in 1989, after adjusting for inflation. Despite sizable recent losses, the average wealth of middleaged and older families in 2010 remained significantly higher than in 1989.

Changes in average family incomes across age groups were qualitatively similar. The smallest percentage declines between 2007 and 2010 were among older families and the largest declines were among younger families, although the differences across age groups were smaller for income than for net worth. As was true for net worth, average inflation-adjusted income was lower only for younger families in 2010 than in 1989. 


\section{Emmons and Noeth}

\section{Table 1}

Decomposition in Mean Inflation-Adjusted Net Worth (All Families, 2007-10)

\begin{tabular}{|c|c|c|c|}
\hline All families & 2007-10 Change (\$) & 2007-10 Change (\%) & $\begin{array}{l}\text { Contribution to decline } \\
\text { in net worth (\%) }\end{array}$ \\
\hline \multicolumn{4}{|l|}{ Changes in: } \\
\hline Durable goods & $-1,338$ & -5.43 & 1.5 \\
\hline Financial and business assets & $-40,301$ & -10.27 & 45.6 \\
\hline Residential real estate & $-50,885$ & -18.99 & 57.5 \\
\hline Total assets & $-92,525$ & -13.51 & 104.6 \\
\hline \multicolumn{4}{|l|}{ Less changes in: } \\
\hline Non-mortgage debt & 210 & 1.36 & 0.2 \\
\hline Mortgage debt & $-4,271$ & -4.95 & -4.8 \\
\hline Total liabilities & $-4,061$ & -3.99 & -4.6 \\
\hline \multicolumn{4}{|l|}{ Equals: } \\
\hline Change in net worth & $-88,464$ & -15.16 & 100.0 \\
\hline
\end{tabular}

Median net worth and income changes were largely consistent with changes in the meansalbeit with fewer stark distinctions between younger and middle-aged families (see Emmons and Noeth, 2012b). The percentage wealth declines measured for the younger and middle-aged families at their medians between 2007 and 2010 (-37.6 percent and -42.5 percent, respectively) were similar. These declines were much larger than the decline in the median net worth among older families measured in 2007 and 2010 (-6.3 percent).

\section{A Balance-Sheet "Waterfall" to Illustrate Contributions to Net Worth Declines}

As a matter of accounting, a family's net worth equals the value of its assets minus the value of its liabilities. As a corollary, the change in net worth equals the sum of changes in all asset categories minus the sum of changes in all liability categories. Thus, net worth declines when an asset category decreases or when a liability category increases, holding all else constant. Conversely, net worth rises when an asset increases or when a liability decreases.

Table 1 displays a simple accounting decomposition of the change between the 2007 and 2010 surveys in the mean inflation-adjusted net worth of all families. Changes in broad balance-sheet categories sum down the page, constituting a "waterfall" of individual contributions that drop down to the total change in net worth at the bottom. The first column of numbers shows the change between 2007 and 2010 in the average inflation-adjusted value of three asset categories and two liability categories, as well as the left-hand side (assets) and right-hand side (liabilities) of the balance-sheet totals. The largest change in an asset category was a $\$ 50,885$ decline in the average inflation-adjusted value of residential real estate between 2007 and 2010. The largest change in a liability category was a \$4,271 decline in the average inflation-adjusted value of mortgage debt, which, through balance-sheet arithmetic, contributed the same amount toward increasing the average family's net worth. 


\section{Figure 1}

\section{Homeownership Rate by Age Group}

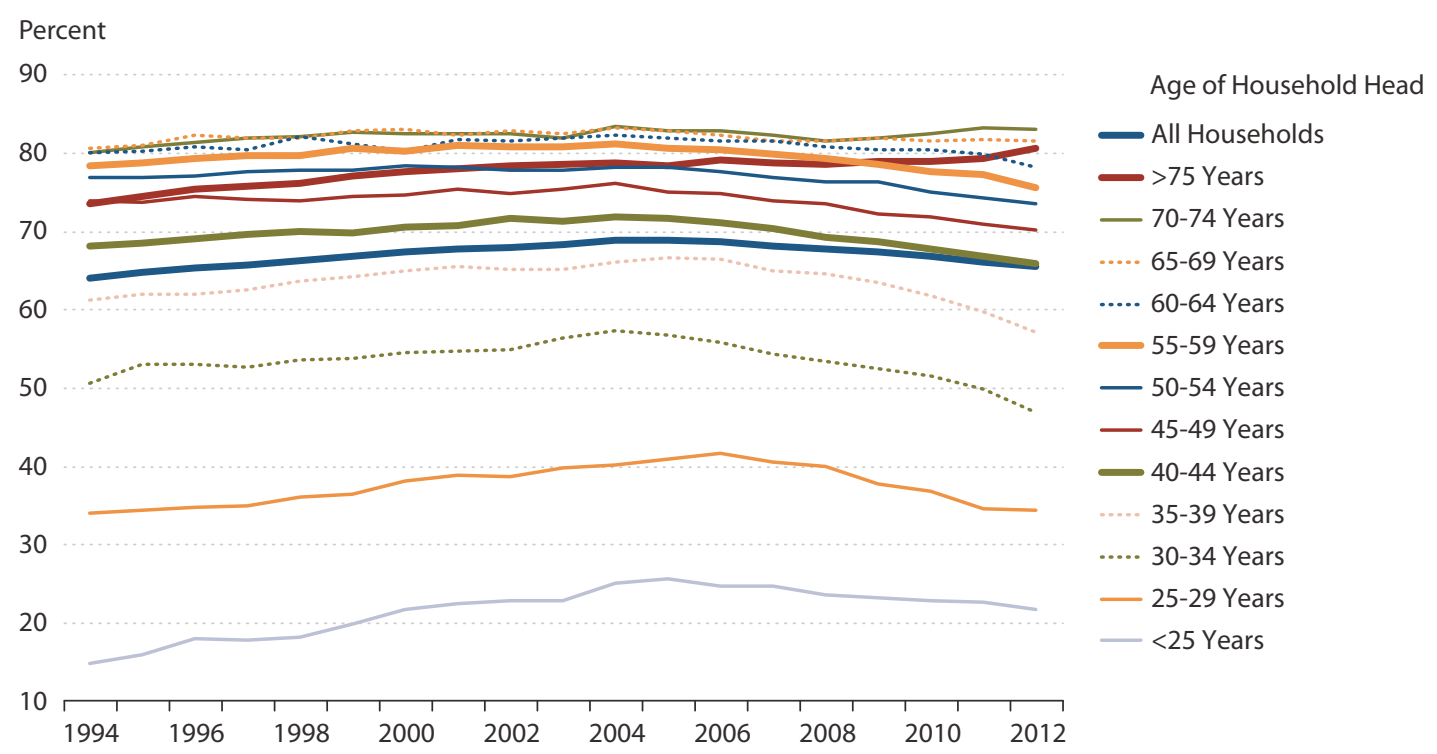

NOTE: Data for 2012 are third quarter, not seasonally adjusted.

The second column of numbers in Table 1 translates the dollar changes in each line into percent changes. The individual percent changes in this column do not sum to the percent change in net worth at the bottom because each percent change refers only to that line item. The third column of numbers provides a decomposition of the average family's change in inflationadjusted net worth between 2007 and 2010 into percent contributions by each balance-sheet component.

The decline in the average value of residential real estate on the balance sheets of all families between 2007 and 2010 contributed 57.5 percent of the total change in net worth. A decline in the average value of financial and business assets contributed 45.6 percent of the change in net worth, and a small decline in the average value of durable goods contributed 1.5 percent of the change in net worth. A \$4,061 decrease in liabilities between 2007 and 2010 contributed a positive 4.6-percentage-point change to net worth.

\section{HOMEOWNERSHIP AND BORROWING TRENDS AMONG YOUNGER FAMILIES}

This section documents housing, mortgage, and net-worth trends across our three broad age groups. In the next section, we disaggregate the balance sheets of young families along the dimensions of educational attainment and race or ethnicity. 


\section{Emmons and Noeth}

\section{Figure 2A}

\section{Cumulative Change in Homeownership Rate Since 1994 by Age Group: All 5-Year Age Groups Younger than 40 Years}

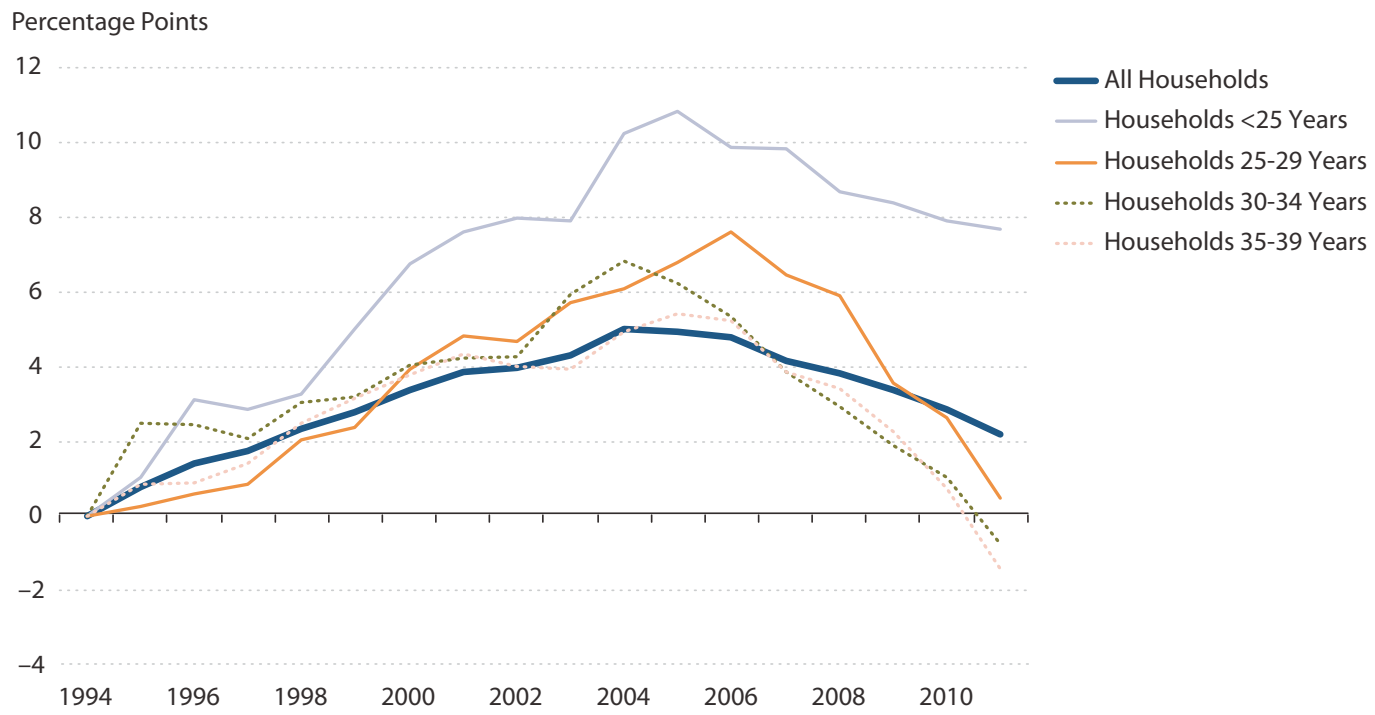

\section{Homeownership Rates}

The overall homeownership rate increased about 5 percentage points between 1994 and 2004, from 64 percent to 69 percent (Figure 1). .6 By age group, the homeownership rate increased more than the national average during the housing boom (peaking variously between 2004 and 2006) among all 5-year age groups with household heads younger than 40 years (Figure 2A). The homeownership rate among all 5-year age groups with household heads between 40 and 74 years rose less than the national average (Figures 2B and 2C). The open-ended age group covering household heads aged 75 and older increased slightly faster than the national average during the boom.

The increases in homeownership rates among young households were large. Among households headed by someone younger than age 25 , for example, the homeownership rate increased from about 15 percent to almost 26 percent, or about 11 percentage points, between 1994 and 2005-more than twice as large as the population average. Among households headed by someone between 25 and 29 years of age, the homeownership rate increased from about 34 percent to almost 42 percent, about 8 percentage points. At the other end of the age spectrum, households headed by someone 75 years or older experienced an increase of about 6 percentage points between 1994 and 2006.

Since its peak in the 2004-06 period, the homeownership rate has declined in virtually every 5 -year age group every year since then. Only the four groups with household heads younger than age 40 and the 75 and older group increased by more than the national average while the 


\section{Figure 2B}

\section{Cumulative Change in Homeownership Rate Since 1994 by Age Group: All 5-Year Age Groups 40-59 Years}

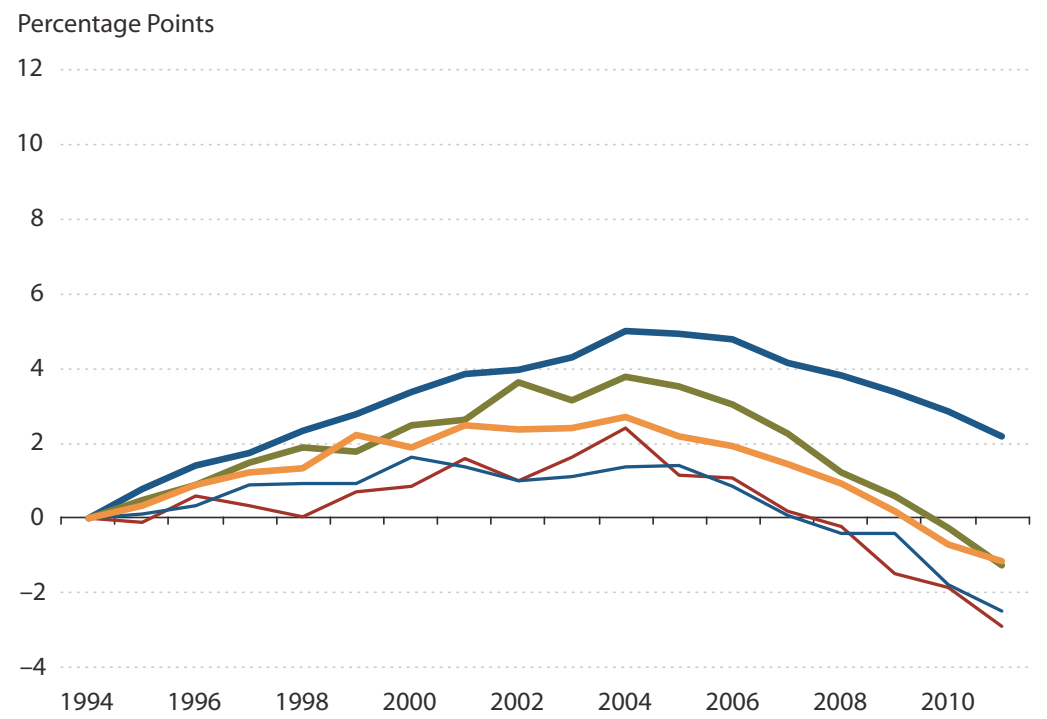

SOURCE: U.S. Census Bureau.

\section{Figure 2C}

\section{Cumulative Change in Homeownership Rate Since 1994 by Age Group:} All 5-Year Age Groups 60 Years and Older

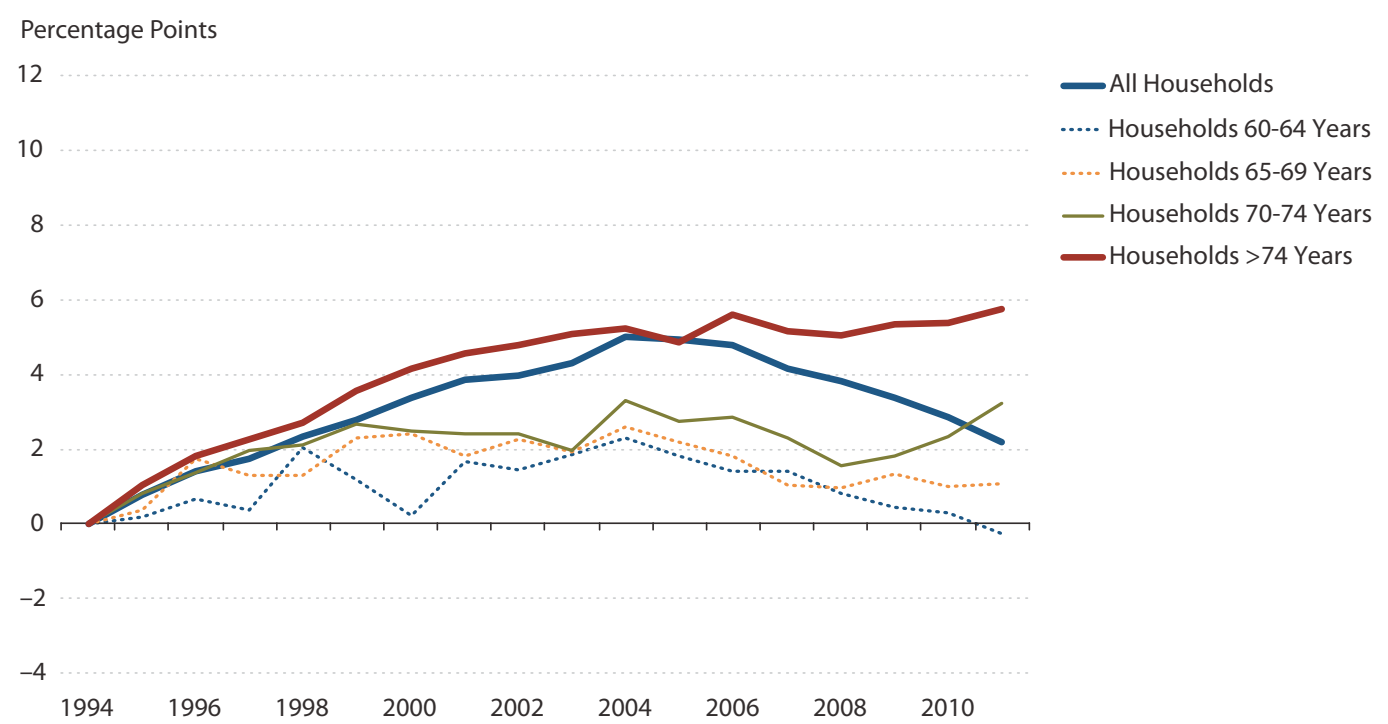




\section{Emmons and Noeth}

\section{Figure 3}

\section{Average Ratio of Residential Real Estate Assets to Income (Homeowners and Renters)}

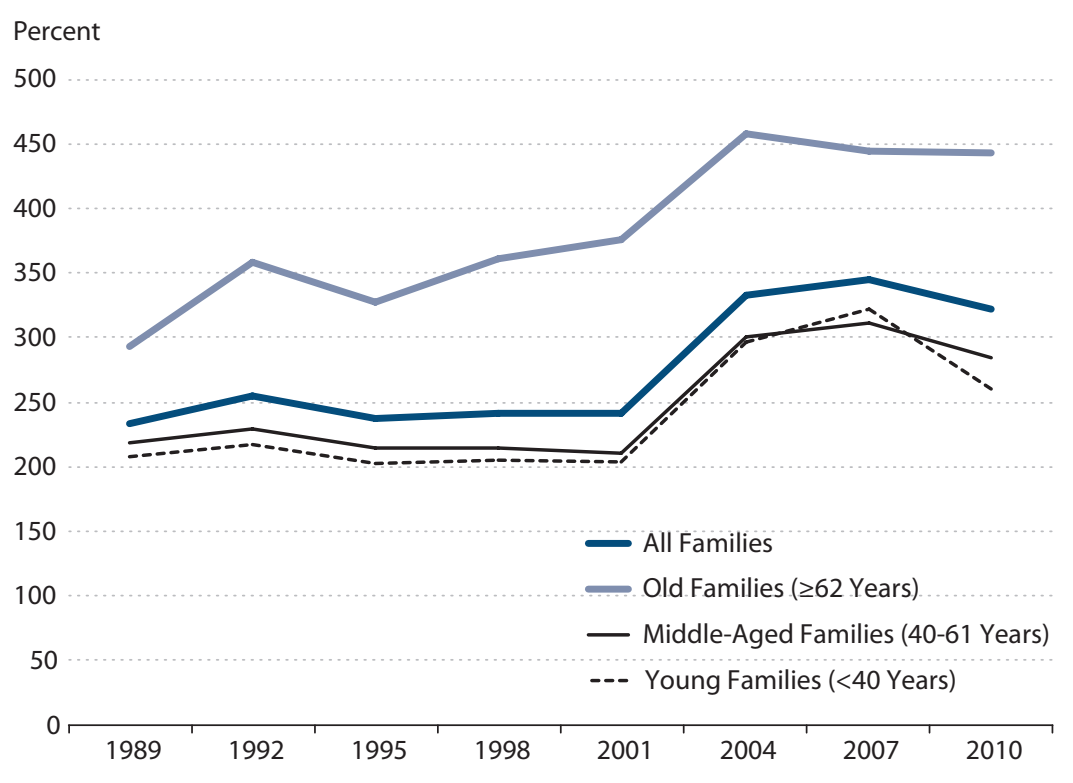

SOURCE: Survey of Consumer Finances.

boom was ongoing. After mid-decade, homeownership rates fell sharply in all age groups except the 65 and older groups. Only among households headed by someone 70 years or older has the homeownership rate continued to reach new highs in recent years. This may be due to some older homeowners delaying the sales of their homes in hopes that prices will rebound soon, or it could be due to changes in the age structure within the oldest age group, which covers the openended interval from 75 years upward. We return to the behavior of the oldest households later.

\section{Ratios of Residential Real Estate Assets to Income and to Total Assets}

Income. The average ratio of residential real estate assets to income among young families increased noticeably between the 2001 and the 2007 surveys, as it also did for other age groups. Increases in both the incidence of homeownership among families of a certain age group (the extensive margin) and average housing values (the intensive margin) caused the ratios to rise; Figure 3 captures the combined effect of changes along both these margins of homeownership. Between 2007 and 2010, the extensive margin (declining homeownership rate) and the intensive margin (falling house prices) both contributed to greater declines for younger families than for older families.

Among home-owning families alone (i.e., excluding the extensive margin's contribution to changes), the ratio of residential real estate assets to income increased most sharply between 2001 and 2007 among the young - by 119 percentage points compared with 101 percentage points among middle-aged homeowners and 68 percentage points among older families (not shown). The subsequent decline between 2007 and 2010 was greatest among young families- 


\section{Figure 4}

\section{Average Portfolio Share of Residential Real Estate among All Families}

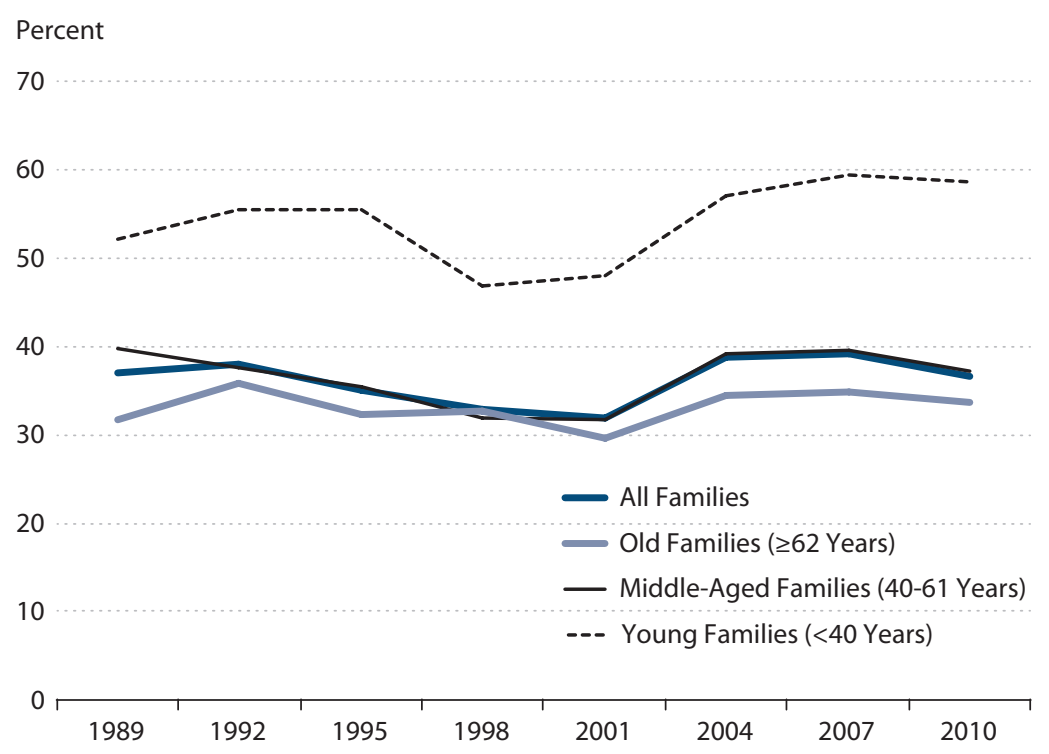

SOURCE: Survey of Consumer Finances.

down 62 percentage points compared with 27 percentage points among middle-aged families and a mere 1 percentage point among older families (Emmons and Noeth, 2012b).

Total Assets. Figure 4 shows that the asset portfolios of young families have long been more heavily concentrated in residential real estate than have those of middle-aged or older families. The average share of housing in the overall asset portfolio for young families increased 11.3 percentage points between 2001 and 2007, compared with 7.9 and 5.3 percentage points for middle-aged and older families, respectively. The 2007-10 decline in the housing portfolio share among young families was slightly less than for the two other groups, leaving the 2010 housing portfolio share of young families still at a historically high level (58.5 percent). Compared with their respective housing portfolio shares in 1989, the share for young families was 6.5 percentage points higher in 2010, while the share for middle-aged families was 2.5 percentage points lower and the share for older families was just 1.9 percentage points higher.

Interestingly, much of the economics and finance literature on housing either takes the high housing portfolio concentration of younger families as a given ${ }^{7}$ or ignores life cycle differences in housing portfolio shares altogether. $\frac{8}{}$ Thus, the high concentration of young families' portfolios in housing, together with high balance-sheet leverage, remains a promising area for future research.

\section{Mortgage Incidence}

The share of young homeowners with any mortgage debt has been higher than the respective shares of middle-aged and older homeowners for at least as long as the SCF has been gath- 


\section{Emmons and Noeth}

\section{Figure 5}

\section{Share of Homeowners with Mortgage Debt}

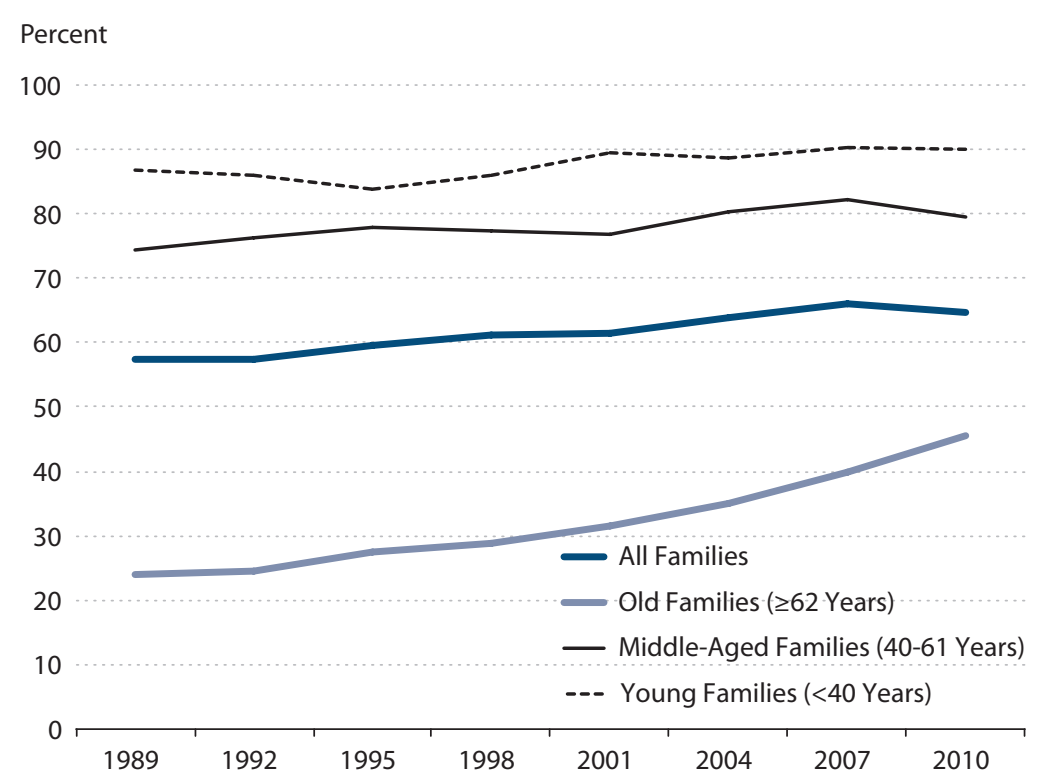

SOURCE: Survey of Consumer Finances.

ering data. This finding is consistent with a life cycle interpretation of mortgage borrowing, in which families borrow when young and seek to pay off their indebtedness over time, rather than maintaining a relatively constant debt-to-equity ratio, as would be typical of a mature business corporation, for example.

Figure 5 shows that between 80 percent and 90 percent of homeowners headed by someone younger than age 40 had mortgage debt in each of the eight surveys since 1989, compared with a somewhat lower share of middle-aged homeowners and a much lower share of older homeowners. A remarkable feature of the data revealed by Figure 5 is that the share of older homeowners with mortgage debt almost doubled between 1989 and 2010, from 24 percent to 46 percent. This feature is not consistent with a simple life cycle interpretation of mortgage borrowing and probably is due to the increasing use of home equity by older homeowners as a source of liquidity. 9 The significant increase over time in the share of older families with mortgage debt is striking, but the incidence of 46 percent in 2010 still is only about half the rate of young families, at 90 percent.

\section{Mortgage Debt Ratios}

In contrast to rising debt-to-income (DTI) ratios and real estate portfolio shares between 2001 and 2007 (see Figures 3 and 4), the ratios of mortgage debt to the value of residential real estate and of total debt to total assets (DTA) changed somewhat less during the boom years (Figures 6 and 7). 10 This was a result of the rapid appreciation of housing and other asset values. Figure 6 shows that the average ratio of mortgage debt to the value of the residential real estate 


\section{Figure 6}

\section{Average LTV Ratios among Homeowners}

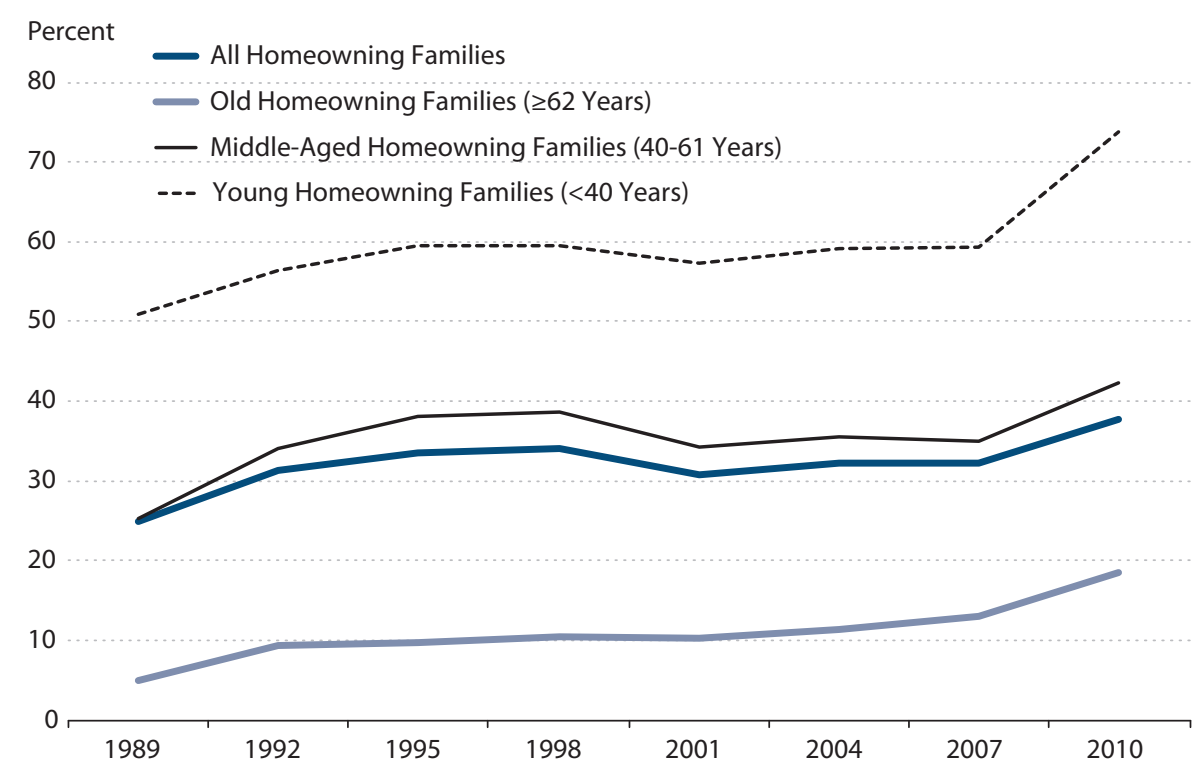

SOURCE: Survey of Consumer Finances.

\section{Figure 7}

\section{Average DTA Ratios among All Families}

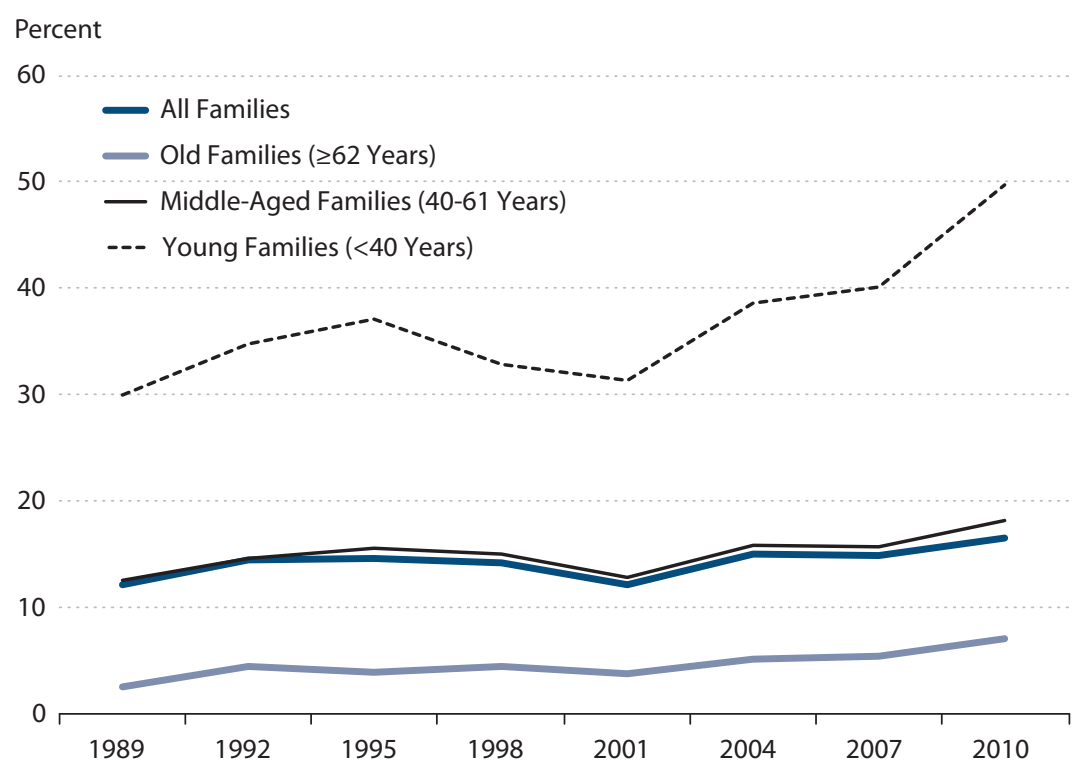

SOURCE: Survey of Consumer Finances. 


\section{Emmons and Noeth}

securing it (the mortgage loan-to-housing value, or LTV ratio) increased only 2 percentage points among young homeowners between 2001 and 2007, from 57 percent to 59 percent. $\underline{11}$ Among middle-aged homeowners, the increase was 0.7 percentage points. Among older homeowners, the increase was 3 percentage points, but the average LTV ratio remained very low in 2007, at 13 percent.

The large decline in housing values that followed 2007, together with the relatively fixed nature of mortgage debt, is reflected in spikes in average LTV ratios in 2010. Among young homeowners in 2010, the reported average LTV ratio was 74 percent, a huge 15-percentagepoint jump from its 2007 level. The average LTV ratios among middle-aged and older homeowning families increased 7 and 5 percentage points, respectively. Compared with 1989 levels, the average LTV ratio among young homeowners in 2010 was 23 percentage points higher, while the ratios were 17 and 14 percentage points higher among middle-aged and older homeowners, respectively.

A broader measure of indebtedness that captures non-mortgage and mortgage debt, all types of assets, and includes both homeowners and renters is the average DTA ratio among all families (see Figure 7). On this metric, deterioration (both short- and long-term) in the balance sheets of young families through 2007 is more evident than when examining the narrower LTV ratio. The average young family substituted 9 percentage points of debt for equity (both measured relative to total assets) in financing its portfolio between 2001 and 2007-that is, the average DTA ratio increased from 31 percent to 40 percent. Between 2007 and 2010, the DTA ratio increased an additional 10 percentage points, largely because asset values declined sharply, destroying equity. Thus, the cumulative substitution of debt for equity on the balance sheet of the average young family amounted to 20 percentage points between 1989 and 2010, moving the average DTA ratio from 30 percent to 50 percent.

Pronounced increases in residential real estate exposure and large increases in leverageeither LTV or DTA-have left the average young family in a weak financial position as of 2010. Even today, some seven or so years after the peak in homeownership rates among young families, the incidence of "negative equity" - when a family's mortgage debt exceeds the market value of the house it secures-is much higher among young homeowners than among homeowners in older age groups. $\frac{12}{}$ Thus, the average young family has much less borrowing capacity and less ability to weather new economic or financial storms than a decade ago. Moreover, the need to strengthen balance sheets by reducing debt means many young families will save more and spend less for some time, detracting from overall economic growth.

\section{The Net-Worth Waterfall for Older, Middle-Aged, and Young Families}

The evidence discussed so far points toward residential real estate as a major contributor to the unusually large wealth losses among young families. The earlier waterfall analysis provides a convenient way to quantify the roles of housing and other balance-sheet items in wealth losses suffered by families of different ages.

Table 2 separates the changes in major asset and liability categories between 2007 and 2010 into the three age categories. For older families, the largest contributor to the decline in wealth between 2007 and 2010 was a $\$ 46,327$ loss in the value of financial and business assets. This represented about 50 percent of the total net-worth loss for this group. Losses in residential real 


\section{Table 2}

Changes in Major Asset and Liability Categories by Age Group (2007-10)

\begin{tabular}{|c|c|c|c|}
\hline Age of families & 2007-10 Change (\$) & 2007-10 Change (\%) & $\begin{array}{l}\text { Contribution to decline } \\
\text { in net worth (\%) }\end{array}$ \\
\hline \multicolumn{4}{|l|}{ Older families ( $\geq 62$ years) } \\
\hline \multicolumn{4}{|l|}{ Changes in: } \\
\hline Durable goods & 418 & 1.60 & -0.5 \\
\hline Financial and business assets & $-46,327$ & -7.73 & 49.9 \\
\hline Residential real estate & $-36,721$ & -11.34 & 39.6 \\
\hline Total assets & $-82,629$ & -8.71 & 89.1 \\
\hline \multicolumn{4}{|l|}{ Less changes in: } \\
\hline Non-mortgage debt & -579 & -6.88 & -0.6 \\
\hline Mortgage debt & 10,697 & 25.28 & 11.5 \\
\hline Total liabilities & 10,118 & 19.95 & 10.9 \\
\hline \multicolumn{4}{|l|}{ Equals: } \\
\hline Change in net worth & $-92,748$ & -10.32 & 100.0 \\
\hline \multicolumn{4}{|c|}{ Middle-aged families (40-61 years) } \\
\hline \multicolumn{4}{|c|}{ Changes in: } \\
\hline Durable goods & $-1,467$ & -5.22 & 1.2 \\
\hline Financial and business assets & $-57,437$ & -12.00 & 47.1 \\
\hline Residential real estate & $-64,819$ & -20.03 & 53.2 \\
\hline Total assets & $-123,723$ & -14.90 & 101.5 \\
\hline \multicolumn{4}{|l|}{ Less changes in: } \\
\hline Non-mortgage debt & 1,560 & 9.17 & 1.3 \\
\hline Mortgage debt & $-3,435$ & -3.04 & -2.8 \\
\hline Total liabilities & $-1,875$ & -1.44 & -1.5 \\
\hline \multicolumn{4}{|l|}{ Equals: } \\
\hline Change in net worth & $-121,847$ & -17.40 & 100.0 \\
\hline \multicolumn{4}{|l|}{ Young families (<40 years) } \\
\hline \multicolumn{4}{|l|}{ Changes in: } \\
\hline Durable goods & $-3,074$ & -16.62 & 4.5 \\
\hline Financial and business assets & $-31,596$ & -32.25 & 46.4 \\
\hline Residential real estate & $-51,014$ & -35.85 & 74.9 \\
\hline Total assets & $-85,685$ & -33.11 & 125.9 \\
\hline \multicolumn{4}{|l|}{ Less changes in: } \\
\hline Non-mortgage debt & -570 & -2.98 & -0.8 \\
\hline Mortgage debt & $-17,044$ & -20.18 & -25.0 \\
\hline Total liabilities & $-17,614$ & -17.00 & -25.9 \\
\hline \multicolumn{4}{|l|}{ Equals: } \\
\hline Change in net worth & $-68,071$ & -43.87 & 100.0 \\
\hline
\end{tabular}




\section{Emmons and Noeth}

estate contributed about 40 percent to the total wealth decline, while an increase in mortgage debt of $\$ 10,697$ contributed another 11.5 percentage points (in an accounting sense) to the average net-worth decline of $\$ 92,748$. The average total decline between 2007 and 2010 was 10.3 percent of 2007 wealth.

The second panel of Table 2 details the sources of net-worth declines among middle-aged families. The most important items were a $\$ 64,819$ average loss in the value of residential real estate (53.2 percent of the total wealth loss) and a $\$ 57,437$ decline in the average value of financial and business assets (47.1 percent of the decline in net worth). Changes in liabilities were of little consequence.

Finally, the third panel in Table 2 reveals that the primary source of loss of wealth among young families between 2007 and 2010 in an accounting sense was their exposure to residential real estate. About 75 percent of the average wealth decline can be traced to the average $\$ 51,014$ decline in housing assets. This is remarkable in light of the fact that only 50 percent of families under 40 were homeowners in 2007. In other words, the losses suffered by young homeowners dominated balance-sheet developments among all young families. Meanwhile, losses on financial and business assets contributed 46 percent, while durable goods contributed 4.5 percent of the average net loss. Unlike either of the other age categories, young families shed a substantial $\$ 17,614$ of total debt, reducing their average net-worth decline by 26 percent.

Of course, this accounting exercise overstates the benefit associated with reducing debt to the extent that some of the debt was eliminated by giving up valuable assets-such as a house or a car-in a default. Moreover, a default, short sale, or other retirement of debt by distressed borrowers exacts a toll on the family's credit rating, which can restrict access to credit and raise future borrowing costs. A voluntary paydown of debt from a family's other resources is a wash from a net-worth perspective because a dollar of assets (cash) is surrendered for each dollar of liability extinguished, leaving net worth unchanged. Reducing debt through scheduled amortization or a voluntary paydown does reduce balance-sheet leverage, however, which reduces the family's sensitivity to further asset price declines.

\section{EDUCATIONAL AND RACE OR ETHNICITY DIMENSIONS OF YOUNG FAMILIES' BALANCE SHEETS}

The SCF allows us to disaggregate young families along a number of demographic dimensions, including educational attainment and race or ethnicity. We distinguish among three levels of educational attainment and between two race or ethnicity categories. The educationalattainment levels are (i) heads of families who have not finished high school ("less than high school" or "dropouts"), (ii) heads of families with a high school diploma or a General Educational Development (GED) certificate ("high school graduates"), and (iii) heads of families with either a two-year or four-year college degree ("college graduates"). Unlike age and education, race and ethnicity questions are asked only of the survey respondent and not the head of the family. Accordingly, our partition of family race and ethnicity is based on the survey respondent. The two race or ethnicity categories are (i) "historically disadvantaged minorities" or "minorities," which includes African Americans and Hispanics of any race; and (ii) whites, Asians, and other 
non-disadvantaged minorities, which we abbreviate as "whites and non-disadvantaged minorities" or "nonminorities."

For ease of exposition, we compare homeownership and debt trends across different levels of educational attainment within the two racial and ethnicity groups separately. We find that both educational attainment and race or ethnicity play important roles in shaping housing and borrowing trends, but these differences generally appear less significant for homeownership and borrowing decisions than those we identified across age categories. In other words, the life cycle may be the most important factor in understanding housing and mortgage borrowing behavior. Young families from different educational and race or ethnicity backgrounds appear more similar to each other than to families of the same race or educational background in older age groups. $\underline{13}$

\section{Homeownership Rates}

Young minority families are significantly less likely to be homeowners than are young nonminority families, holding constant the level of family educational attainment (Figures 8 and 9). Within each racial or ethnic group, college graduates are the most likely and those with less than a high school education are the least likely to be homeowners. Homeownership rates among young families in 2007 ranged from 24 to 56 percent among minority families of different educational-attainment levels and from 52 to 65 percent among nonminority families. These ranges overlap their counterpart ranges for middle-aged and older families only slightly. $\underline{\underline{14}}$

Small sample sizes make inference somewhat tentative, but it appears that the largest increases in homeownership rates in the years preceding 2007 were among college graduates, both minority and nonminority. $\frac{15}{}$ After averaging about 38 percent in the four surveys between 1989 and 1998, the homeownership rate among young minority college graduates averaged about 54 percent in the 2001, 2004, and 2007 surveys. Among young nonminority college graduates, the homeownership rate increased less but from a higher base-from an average of 58 percent during the 1989-98 period to about 63 percent during the 2001-07 period.

Although it is difficult to see in the figures, the increase in the average homeownership rate from the earlier period (1989-98) to the later period (2001-07) was three times as large for minority college graduates as for either minority high school graduates or minority families with less than a high school education. The 5-percentage-point increase for nonminority college graduates was noticeably higher than the 2-percentage-point increase among nonminority families with less than a high school education or the 0.5 -percentage-point decline in the rate for high school graduates.

Homeownership rates for virtually all young groups declined between 2007 and 2010 . Among all young minority families, the 3.5-percentage-point decline in the homeownership rate reversed about half of the increase experienced between the earlier period (1989-98) and the later period (2001-07). For all young nonminority families combined, the 2-percentagepoint increase was completely reversed by 2010 .

\section{Ratios of Residential Real Estate Assets to Income and to Total Assets}

Although young minority families have lower homeownership rates than young nonminority families with the same level of education, the average ratios of residential real estate to household income and to total assets for minority families reached or exceeded corresponding average 


\section{Emmons and Noeth}

\section{Figure 8}

\section{Homeownership Rate among Young Minority Families}

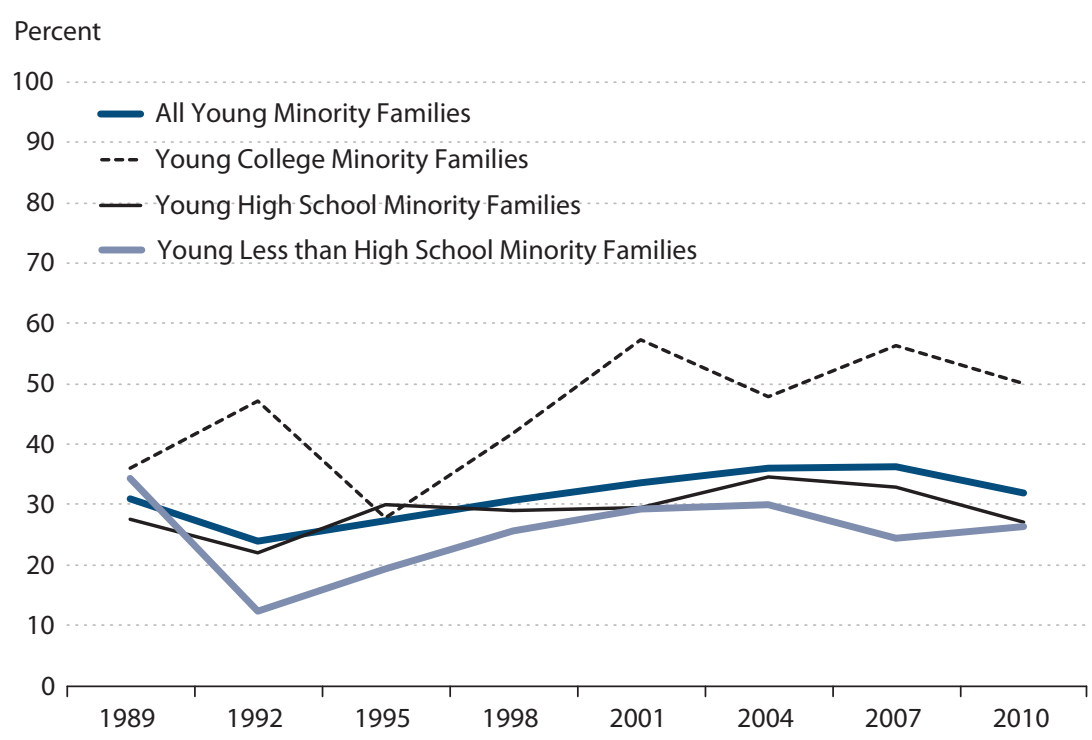

NOTE: Minority includes African Americans and Hispanics of any race.

SOURCE: Survey of Consumer Finances.

\section{Figure 9}

\section{Homeownership Rate among Young Nonminority Families}

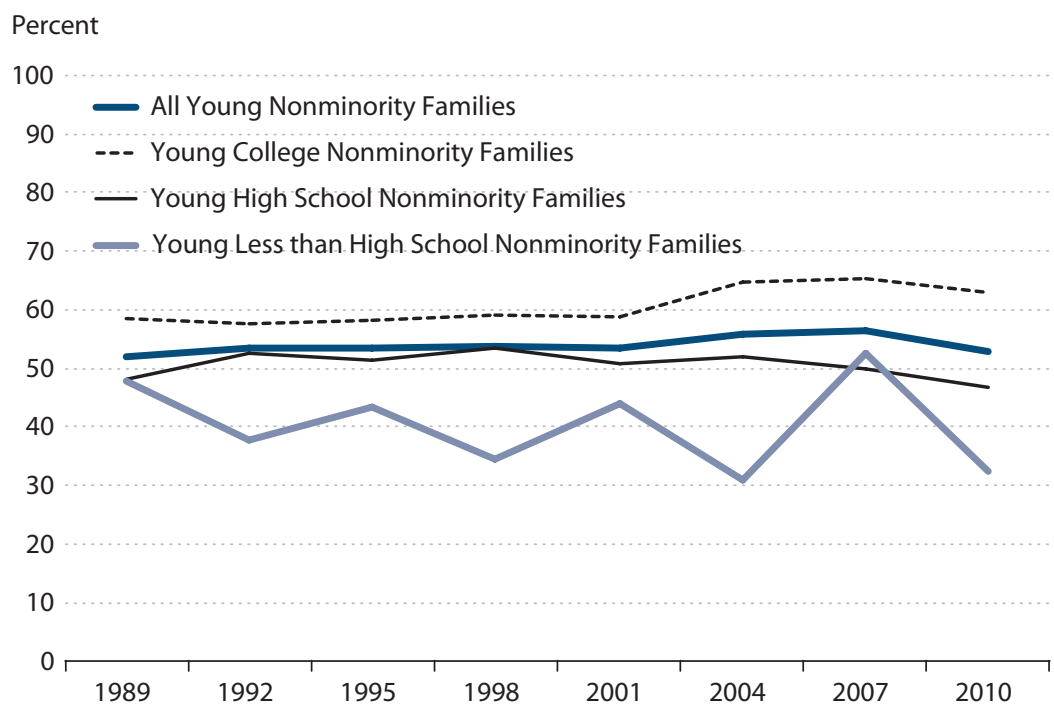

NOTE: Nonminority includes whites, Asians, and other non-disadvantaged minorities.

SOURCE: Survey of Consumer Finances. 


\section{Figure 10}

\section{Ratio of Residential Real Estate Assets to Income of Young Minority Families}

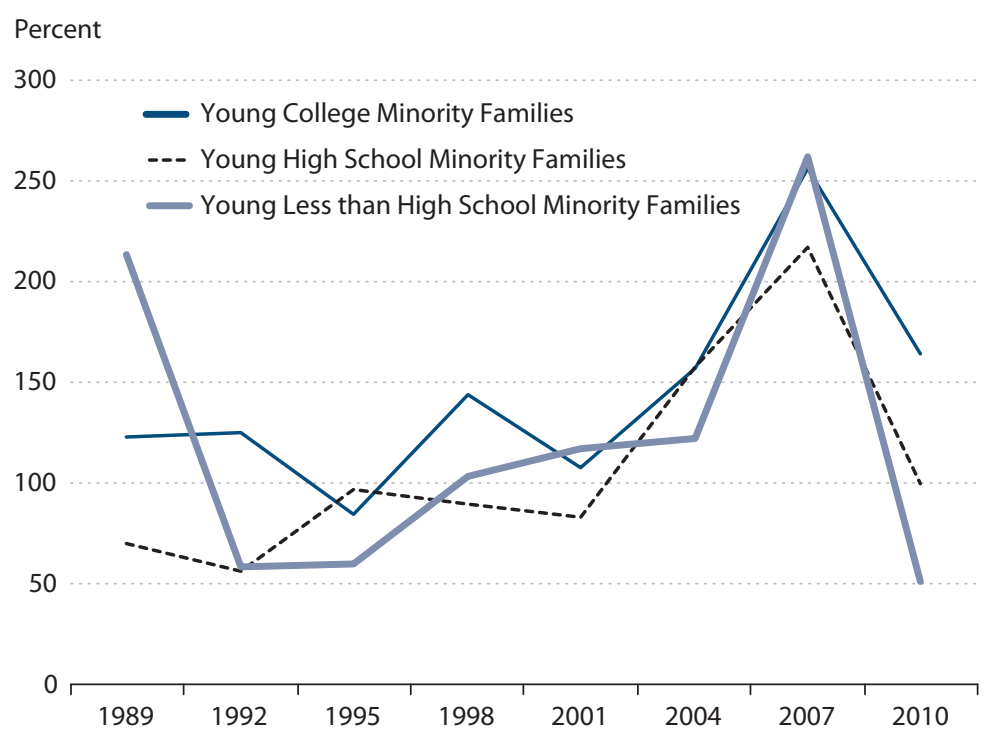

NOTE: Minority includes African Americans and Hispanics of any race.

SOURCE: Survey of Consumer Finances.

\section{Figure 11}

\section{Ratio of Residential Real Estate Assets to Income of Young Nonminority Families}

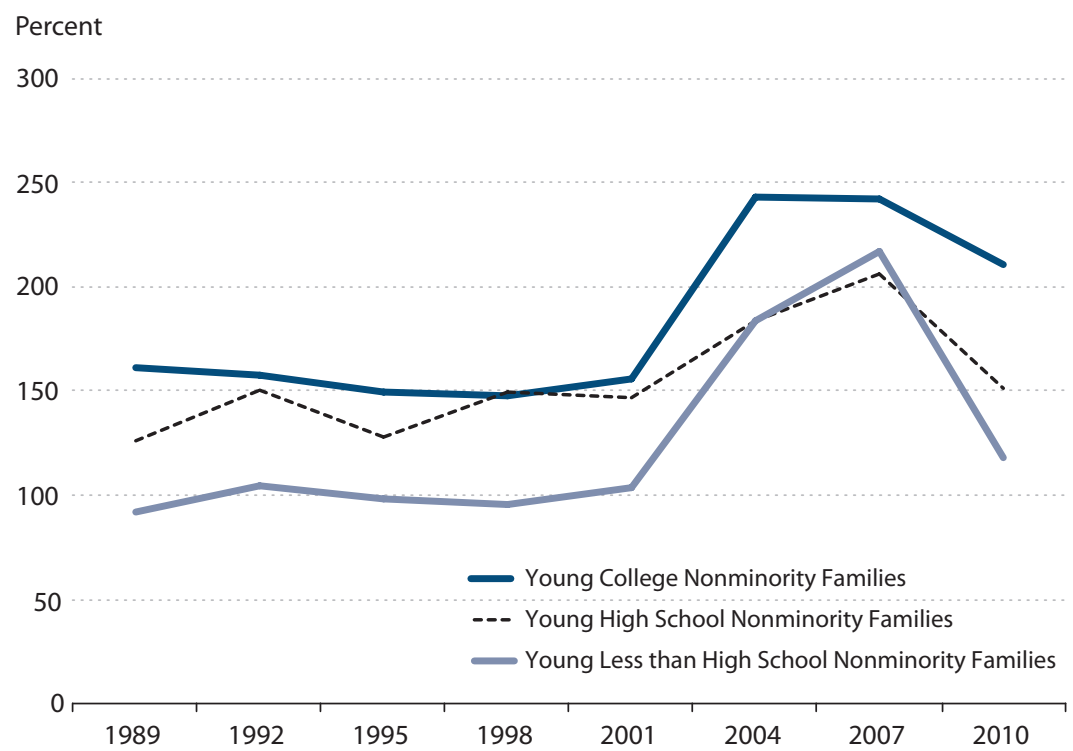

NOTE: Nonminority includes whites, Asians, and other non-disadvantaged minorities.

SOURCE: Survey of Consumer Finances. 


\section{Emmons and Noeth}

levels for nonminorities at the peak of the housing boom (Figures 10 and 11; see Emmons and Noeth, 2012b). In other words, although proportionally fewer young minority families were homeowners, the collective exposure of young minorities to residential real estate by 2007 was comparable to or greater than the exposure faced by young nonminority families. Consequently, those young minority families that were homeowners actually had significantly greater exposure to housing markets than did their nonminority counterparts relative to both income and total assets.

Figure 10 shows that young minority families of all educational levels more than doubled their holdings of residential real estate relative to family income between 2001 and 2007. This surge is particularly noteworthy because the real estate-to-income ratio had been relatively stable before 2001 for all education groups. Figure 11 reveals a remarkably similar pattern among young nonminority families, albeit with a higher typical real estate-to-income ratio before 2001 than among young minority families and, therefore, a somewhat smaller proportionate increase in the ratio between 2001 and 2007. Among young nonminority families, only the group with less than a high school education doubled its average real estate-to-income ratio over that period.

The average portfolio share of real estate generally was higher for young minority families throughout the period covered by the surveys, especially for families with less than a high school education (not shown; see Emmons and Noeth, 2012b). The average real estate portfolio share among young nonminority families was relatively stable before 2001 and then increased through 2007.

Declines in the real estate portfolio share between 2007 and 2010 were particularly sharp for young families with less than a high school education in both racial or ethnic categories. The underlying data reveal that virtually all the decline was due to lower real estate holdings rather than lower income. For young minority families with less than a high school education, the average value of residential real estate owned was 81 percent lower in 2010 than in 2007; average income was only 1 percent lower. For young nonminority families with less than a high school education, the average value of residential real estate owned was 56 percent lower in 2010 than in 2007, while average income was 20 percent lower.

An important risk faced by many young homeowners is the elevated medium- and long-term price volatility of lower-priced homes, which younger families are more likely to buy, compared with the lower volatility of higher-priced homes in the same markets. This feature of many regional housing markets suggests that lower-priced housing itself may be a risk factor that should be recognized.

\section{Mortgage Incidence}

When the survey results for the "pre-boom period"-1989, 1992, 1995, and 1998-were averaged to increase the sample sizes, 74 percent of young minority homeowners had mortgage debt, while 88 percent of young nonminority homeowners had mortgages. During the "boom period" -2001, 2004, and 2007-mortgage incidence was 85 percent and 91 percent for young minority and nonminority families, respectively. In "post-boom" 2010, 82 percent and 92 percent of young minority and nonminority families had mortgage debt, respectively. Thus, mort-

gage incidence rose and fell more among minorities. College-educated young families generally were the most likely to have mortgage debt throughout the entire period. Young families of any 


\section{Figure 12}

\section{Average LTV Ratios among Young Families}

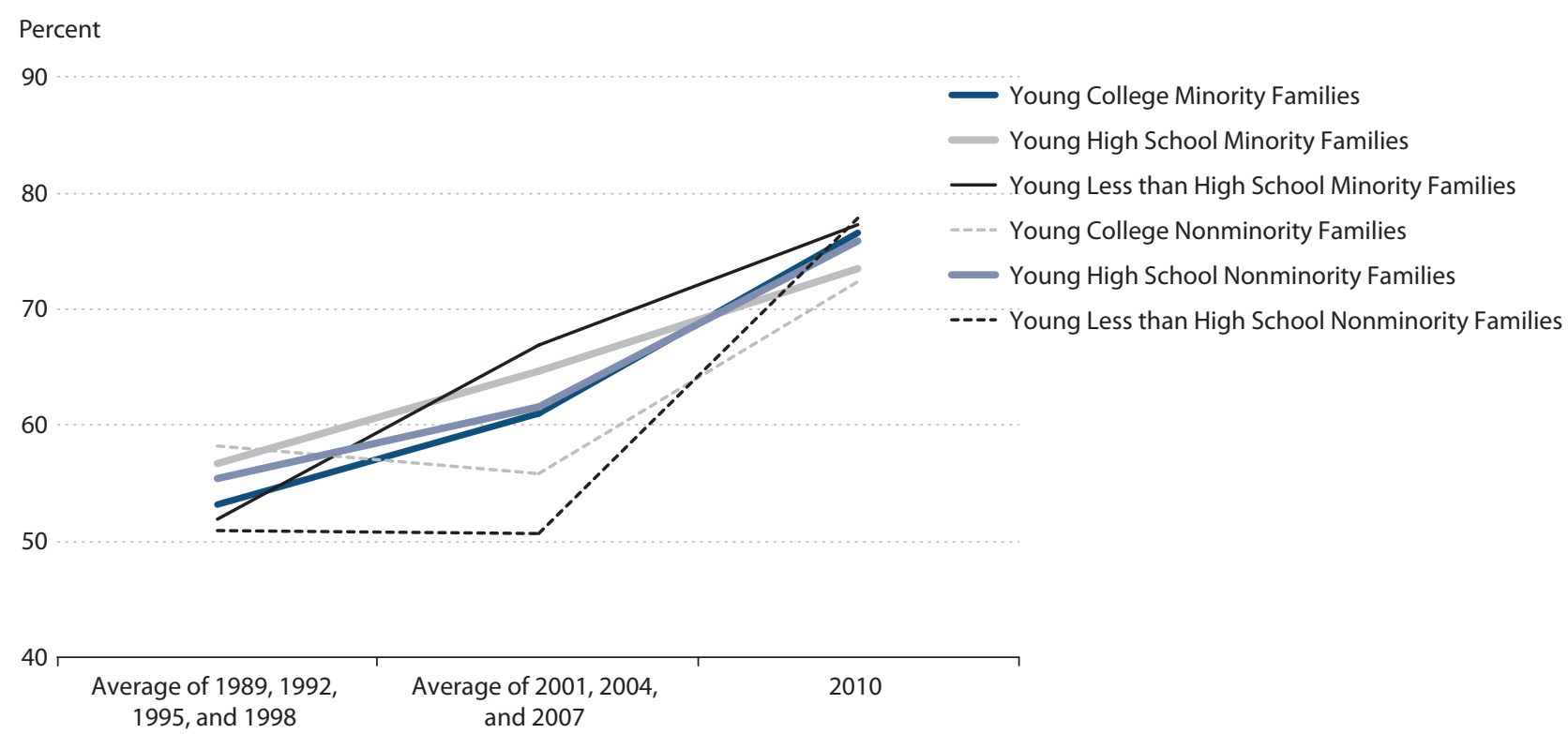

NOTE: Minority includes African Americans and Hispanics of any race. Nonminority includes whites, Asians, and other non-disadvantaged minorities.

SOURCE: Survey of Consumer Finances.

race or ethnicity with less than a high school education were much less likely than other young families to have mortgage debt throughout the period covered by the surveys.

\section{Mortgage and Debt Ratios}

Figure 12 shows average mortgage LTV ratios for all young families in a single chart, again dividing the group along race or ethnicity and educational-attainment dimensions and grouping the surveys into three time periods to increase sample sizes. A jump between the pre-boom 1990s and the housing-boom 2001-07 period occurred in four of the six categories, excluding only nonminority college graduates and nonminority families with less than a high school education.

The increase in average LTV ratios between the 2001-07 average and the 2010 survey was both universal and quantitatively large. The percentage-point increases in average LTV ratios ranged between 9 and 27, with an average across the six groups of 15 percentage points. Most of the increase in LTV ratios was due to falling real estate values rather than increases in mortgage debt.

A broader measure of debt burden is the overall DTI ratio, which includes mortgage and non-mortgage debt in the numerator. The overall pattern is qualitatively similar for young minority and nonminority families, albeit with a few notable differences. White and other nondisadvantaged young families typically had higher average DTI ratios than their disadvantaged counterparts in every year of the survey except 2007 (Emmons and Noeth, 2012b). For young 


\section{Emmons and Noeth}

minority families, average 2007 DTI ratios were more than double their 2001 levels in each educational subgroup. A steep increase in DTI ratios among young minority families between 2001 and 2007 was followed by very sharp declines by 2010. Among all young families, average inflation-adjusted income declined about 12 percent between 2007 and 2010, while average debt decreased about 17 percent. Most of the decline was in mortgage debt.

\section{REGRESSION EVIDENCE: YOUNG FAMILIES WERE UNUSUALLY EXPOSED TO A HOUSING CRASH}

Previous sections showed that homeownership rates among young families increased significantly from the mid-1990s through the mid-2000s before falling back. Moreover, the importance of residential real estate assets to the average young family-both relative to family income and as a share of total assets-increased notably between 2001 and 2007. The incidence and amount of mortgage debt increased also. This section describes regression evidence confirming that younger families were unusually exposed to a housing market crash.

\section{Homeownership Rate and Real Estate Portfolio Concentration}

The family-level detail of the SCF allows us to use a multiple-regression framework to verify the existence of a shift in the propensity for young families to become homeowners, holding many important family characteristics and overall market trends constant. Table 3 presents the results of two logit regressions that use the pooled data from the six surveys conducted in 1992, 1995, 1998, 2001, 2004, and 2007. The 1989 survey was omitted because it did not ask if income exceeded spending, one of our independent variables (to proxy for financial capability). The 2010 data were omitted because our purpose here is to determine whether the homeownership rate among young families was unusually high in 2007, before the housing market crashed. The dependent variable in each regression is equal to 1 if the family owned its primary residence and 0 if it did not.

The results show that a family's educational attainment, age, race, income, saving behavior, marital status, and number of children in the home are statistically significant predictors of whether a particular family is a homeowner. When all of these factors are controlled for in regression (1), there is little difference in the overall homeownership rate in any survey year except 1995. This may seem surprising, given the overall increase in homeownership rates reported in Census data between the mid-1990s and mid-2000s. One explanation for our results is that the changes in the overall homeownership rate were fully explained by changes in the variables in our regression, rather than by an exogenous time trend.

The main result of interest in Table 3 is the last variable in the second regression. In this specification, we included dummy variables that took a value of 1 if a particular observation was of a young family that owned its home in year X, and 0 otherwise, for each of the years 1995, 1998, 2001, 2004, and 2007, using young homeowners in 1992 as the omitted category. The marginally statistically significant coefficient estimate of 0.213 ( $p$-value of 0.083 ) on the interaction dummy variable for young homeowners in 2007 implies that, controlling for all of the other variables in the regression, we observed a higher homeownership rate among young 


\section{Table 3}

Logit Regressions of Homeownership Indicator Variable on Pooled Data from SCF (1992-2007)

\begin{tabular}{|c|c|c|}
\hline \multirow[b]{2}{*}{ Independent variables } & \multicolumn{2}{|c|}{ Regression } \\
\hline & (1) & $(2)$ \\
\hline Intercept & $-0.937^{* * *}$ & $-0.888^{* * *}$ \\
\hline High school or GED dummy (<high school omitted) & $0.387^{* * *}$ & $0.39 * * *$ \\
\hline College graduate dummy (<high school omitted) & $0.601 * * *$ & $0.604^{* * *}$ \\
\hline Age $<40$ dummy (ages 40-61 years omitted) & $-1.365^{* * *}$ & $-1.48^{* * *}$ \\
\hline Age $\geq 62$ dummy (aged 40-61 years omitted) & $0.762^{* * *}$ & $0.76^{* * *}$ \\
\hline Member of minority dummy (nonminority omitted) & $-0.751 * * *$ & $-0.753^{* * *}$ \\
\hline Square root of income & $0.098^{* * *}$ & $0.098^{* * *}$ \\
\hline Saved within the past year dummy & $0.45^{* * *}$ & $0.45^{* * * *}$ \\
\hline Married dummy & $1.07^{* * *}$ & $1.07^{* * *}$ \\
\hline No. of children in family & $0.171^{* * *}$ & $0.171^{* * *}$ \\
\hline 1995 year dummy (1992 omitted) & $0.137^{* *}$ & 0.079 \\
\hline 1998 year dummy (1992 omitted) & -0.052 & -0.108 \\
\hline 2001 year dummy (1992 omitted) & -0.07 & -0.122 \\
\hline 2004 year dummy (1992 omitted) & 0.033 & -0.008 \\
\hline 2007 year dummy (1992 omitted) & 0.029 & -0.056 \\
\hline <40 TIMES 1995 year dummy (1992 omitted) & & 0.133 \\
\hline <40 TIMES 1998 year dummy (1992 omitted) & & 0.129 \\
\hline <40 TIMES 2001 year dummy (1992 omitted) & & 0.12 \\
\hline <40 TIMES 2004 year dummy (1992 omitted) & & 0.089 \\
\hline <40 TIMES 2007 year dummy (1992 omitted) & & $0.213^{*}$ \\
\hline Observations (first implicate) & 25,889 & 25,889 \\
\hline \multicolumn{3}{|c|}{$\begin{array}{l}\text { NOTE: Unweighted regressions using repeated-imputation inference techniques (see Montalto and Sung, 1996). }{ }^{* * *} \text {, and *** indicate statisti } \\
\text { cal significance at the } 10 \text { percent, } 5 \text { percent, and } 1 \text { percent confidence levels, respectively. DTA ratios greater than } 10 \text { are omitted. Minority } \\
\text { includes African Americans and Hispanics of any race; nonminority includes whites, Asians, and other non-disadvantaged minorities. }\end{array}$} \\
\hline \multicolumn{3}{|c|}{ SOURCE: Data from 1992-2007 pooled longitudinal SCF surveys. } \\
\hline
\end{tabular}

families in 2007 than we would have expected. That is, there is statistical evidence that homeownership among young families was elevated in 2007 relative to "normal" levels, including fundamental determinants of that rate.

\section{Borrowing by Young Families}

We also investigated the determinants of LTV ratios (not shown; see Emmons and Noeth, 2012b). We find (i) that higher levels of education are associated with higher LTV ratios and (ii) there is a clear life cycle pattern as young families have higher and older families have lower LTV ratios than middle-aged families. Controlling for many factors, members of minority groups have slightly higher LTV ratios. The important result for our purposes is that the interaction dummy variable in the second regression that would pick up an unusual change in the LTV ratio among young homeowners during the boom years is insignificant. Thus, the empirical model indicates that LTV ratios among young homeowners were not exceptional during the boom 


\section{Emmons and Noeth}

\section{Table 4}

Ordinary Least Squares Regression of DTA Ratio on Pooled Data from SCF (1992-2007)

\begin{tabular}{|c|c|c|}
\hline \multirow[b]{2}{*}{ Independent variables } & \multicolumn{2}{|c|}{ Regression } \\
\hline & (1) & (2) \\
\hline Intercept & $0.367^{* * *}$ & $0.368^{* * *}$ \\
\hline High school or GED dummy (<high school omitted) & $0.031^{* *}$ & $0.032^{* *}$ \\
\hline College grad dummy (<high school omitted) & 0.023 & 0.023 \\
\hline Age $<40$ dummy (ages 40-61 years omitted) & $0.306^{* * *}$ & $0.306^{* * *}$ \\
\hline Age $\geq 62$ dummy (ages 40-61 years omitted) & $-0.17^{* * *}$ & $-0.17^{* * *}$ \\
\hline Member of minority dummy (nonminority omitted) & $0.051^{* * *}$ & $0.05^{* * *}$ \\
\hline Square root of income & $-0.002^{* * *}$ & $-0.002^{* * *}$ \\
\hline Saved within the past year dummy & $-0.143^{* * *}$ & $-0.144^{* * *}$ \\
\hline Married dummy & $-0.06^{* * *}$ & $-0.061^{* * *}$ \\
\hline No. of children in family & -0.002 & -0.002 \\
\hline 1995 year dummy (1992 omitted) & 0.015 & $0.031^{*}$ \\
\hline 1998 year dummy (1992 omitted) & $0.028^{*}$ & 0.021 \\
\hline 2001 year dummy (1992 omitted) & 0.016 & 0.02 \\
\hline 2004 year dummy (1992 omitted) & $0.056^{* * *}$ & $0.06^{* * *}$ \\
\hline 2007 year dummy (1992 omitted) & $0.074^{* * *}$ & $0.057^{* * *}$ \\
\hline <40 TIMES 1995 year dummy (1992 omitted) & & $-0.055^{*}$ \\
\hline <40 TIMES 1998 year dummy (1992 omitted) & & 0.024 \\
\hline <40 TIMES 2001 year dummy (1992 omitted) & & -0.014 \\
\hline <40 TIMES 2004 year dummy (1992 omitted) & & -0.017 \\
\hline <40 TIMES 2007 year dummy (1992 omitted) & & $0.074^{* *}$ \\
\hline R-squared (first implicate) & 0.11 & 0.11 \\
\hline Observations (first implicate) & 25,115 & 25,115 \\
\hline
\end{tabular}

NOTE: Unweighted regressions using repeated-imputation inference techniques (see Montalto and Sung, 1996$) .{ }^{*},{ }^{* *}$, and ${ }^{* * *}$ indicate statistical significance at the 10 percent, 5 percent, and 1 percent confidence levels, respectively. Minority includes African Americans and Hispanics of any race; nonminority includes whites, Asians, and other non-disadvantaged minorities.

SOURCE: Data from 1992-2007 pooled longitudinal SCF surveys.

after controlling for other factors. This confirms our conclusion from the raw data displayed in Figure 6.

Table 4 reports the results of regressions of a broader measure of debt burden on a number of potential determinants. The dependent variable is the DTA ratio. The key result is that, when controlling for a variety of factors, the average DTA ratio was unusually high among all families in 2004 and 2007, as shown by significant positive coefficient estimates on the dummy variables for those years in both regressions. In addition, the young family-year interaction dummy variable for 2007 in regression (2) also was significantly positive. This means that young families, on average, had higher DTA ratios in 2007 than we would have expected based on a host of fundamental factors and controlling for time trends.

We performed the same exercise using the total DTI ratio as the dependent variable (Emmons and Noeth, 2012b). The qualitative result is the same as in Table 4: There were significantly 
Emmons and Noeth

\section{Table 5}

\section{Panel Regression of Indicator Variable for Any Delinquency of at Least Two Months within Year before Re-interview in 2009 on Data from SCF Panel (2007-09)}

\begin{tabular}{lc}
\hline Intercept & $-2.176^{* * *}$ \\
High school or GED dummy (<high school omitted) & -0.235 \\
College graduate dummy (<high school omitted) & $-0.671^{* *}$ \\
Age $<40$ dummy (ages 40-61 years omitted) & -0.064 \\
Age $\geq 62$ dummy (ages 40-61 years omitted) & -0.547 \\
Member of minority dummy (nonminority omitted) & 0.102 \\
Square root of income & $0.013^{* *}$ \\
Saved within the past year dummy & $-0.418^{* *}$ \\
Married dummy & -0.071 \\
No. of children in family & $0.132^{* *}$ \\
Square root of liquid assets & $-0.002^{*}$ \\
Square root of available credit & $-0.004^{* * *}$ \\
DTI ratio & $0.081^{* * *}$ \\
History of past credit problems & $0.783^{* * *}$ \\
Homeowner & $-0.593^{* *}$ \\
Mortgage LTV ratio & $1.023^{* * *}$ \\
Unemployment spell in 2008-09 & $0.687^{* * *}$ \\
Sickness in 2008-09 & -0.207 \\
Observations (first implicate) & 2,801
\end{tabular}

NOTE: Unweighted regressions using repeated-imputation inference techniques (see Montalto and Sung, 1996). ${ }^{*}, * *$ and ${ }^{* * *}$ indicate statistical significance at the 10 percent, 5 percent, and 1 percent confidence levels, respectively. Minority includes African Americans and Hispanics of any race; nonminority includes whites, Asians, and other non-disadvantaged minorities.

SOURCE: Data from 2007-09 panel SCF survey.

higher DTI ratios across the entire sample in 2004 and 2007, and among young families in 2004, near the height of the boom, the average DTI ratio was elevated even further.

\section{After the Crash: Delinquency Rates}

The 2007-09 SCF panel dataset allows us to track individual families during the most intense phase of the financial crisis and recession. The model described in Table 5 uses as its dependent variable a dummy variable that equals 1 if a family has experienced a spell of delinquency of two months or longer within the year preceding the 2009 re-interview on any debt. The sample is restricted to those with any debt in 2007.

Unsurprisingly, a spell of unemployment is a strong predictor of delinquency, although sickness was not. Families with lower levels of education and more children had more delinquencies. Variables that may proxy for higher levels of financial capability-such as saving, holding liquid assets, borrowing less than their available credit, and avoiding past credit problems-also predicted fewer delinquencies. Holding everything else constant, homeowners had significantly fewer delinquencies. This may indicate that mortgage debt was easier to refinance than the forms of debt renters held, allowing homeowners to avoid some delinquencies. 


\section{Emmons and Noeth}

Of more immediate interest for us are the significant positive coefficients on a family's LTV and DTI ratios in 2007. The significance of these ratios suggests that the sources of delinquency were not unusual during the recent downturn. Nor was youth per se a risk factor. Instead, it was individual young families' exposure to well-known risk factors such as high debt ratios that mattered. As we found earlier, many younger families had incurred high levels of debt, especially in the form of mortgages. Elevated delinquency rates, therefore, are not surprising.

\section{CONCLUSION}

The financial hardships suffered by many younger families during the recent financial crisis and recession reinforce a trend of widening wealth disparity across age groups over the past 20 years. The average inflation-adjusted net worth of a middle-aged or older family increased by 38 percent and 68 percent, respectively, between 1989 and 2010. The average net worth of a family headed by someone younger than 40 years of age was 26 percent lower in 2010 than it was in 1989. We showed that rising exposure of young families to homeownership, financed largely with mortgage debt, was a significant factor in the continuation during the crisis of this long-standing age-based disparity in wealth accumulation.

In particular, we documented a large boom and bust in homeownership and mortgage borrowing among young families in recent years. We found that, in an accounting sense, about three-quarters of the wealth decline for the average young family between 2007 and 2010 was due to its exposure to residential real estate. For middle-aged and older families, housing losses contributed only about 53 percent and 40 percent of the total wealth decline, respectively. Regression evidence suggested that young families were unusually highly concentrated in housing, with abnormally high debt levels, just as the housing market crashed.

Even after large declines in homeownership rates, the value of real estate holdings, and debt outstanding, young families remained highly exposed to real estate risk in 2010. Housing represented about 53 percent of the average young family's assets in 2010, while the average DTI ratio remained 158 percent (of which 78 percent was mortgage debt). By way of contrast, the average housing portfolio share of young families was only 43 percent in 2001, while the average DTI ratio was 102 percent. If housing markets and the economy remain weak, many young families will continue to struggle in achieving or maintaining financial stability.

\section{NOTES}

1 Data are from the Federal Reserve's Survey of Consumer Finances, conducted in its current form triennially since 1989. The latest wave available was from 2010; the next wave will be conducted during 2013. All amounts listed are in 2010 inflation-adjusted dollars.

$\underline{2}$ We use both "family" and "household" in our article to reflect the preferred terminologies of our data sources. The $\mathrm{SCF}$, our primary data source, uses "family" to refer to the primary economic unit. However, in the second section of the paper, we discuss Census homeownership data from the Census Bureau, which uses "household" to refer to occupied housing units.

3 A short sale is a home sale for less than the value of all outstanding mortgage debt. Like a default, a short sale requires the homeowner to give up the house and it wipes out the mortgage debt. A principal reduction involves the forgiveness of some mortgage debt without loss of the home. All three transactions damage the borrower's credit rating but increase the borrower's net worth because the value of debt being extinguished exceeds the value 
of the assets surrendered - the house in case of short sale or default; nothing in a principal reduction. All three transactions normally create taxable income to the borrower in the amount of the "deficiency," in cases of default, short sale, or debt forgiveness. The Mortgage Forgiveness Debt Relief Act of 2007 exempted borrowers from taxation on their canceled debts during calendar years 2007 through 2012.

4 See Bricker et al. (2012) and Emmons and Noeth (2012a) for detailed discussions of recent findings in the SCF.

$\underline{5}$ Our decision to define groups with cutoffs at 40 and 62 years of age reflects a number of considerations. To maintain roughly equal group sizes over the entire study period, on average, an upper cutoff of about 55 years would have been better. However, our focus in this article is on homeownership, which suggested an upper cutoff age in the upper 60 s or even 70 , the point in the life cycle when the homeownership rate appears to stabilize. Our choice of age 62 represents a compromise, also motivated in part by the fact that 62 is the age at which Social Security benefits are first available. A large movement out of employment occurs at about this age.

6 U.S. Census Bureau.

$\underline{7}$ Flavin and Yamashita (2002) analyze the effect of a family's exogenously determined housing portfolio share on the composition of its optimal portfolio of financial assets and its choice of leverage. They note the empirical fact but do not explain why younger families typically have higher housing portfolio shares than do unconstrained (wealthier and usually older) families. The elevated housing share and accompanying high leverage (both relative to net worth) create a risky portfolio. Flavin and Yamashita show that, regardless of the degree of a family's risk aversion, its optimal portfolio share invested in stocks increases and its housing portfolio share decreases over the life cycle as wealth increases. Younger families hold more housing and bonds but fewer stocks because this asset mix reduces overall portfolio risk given an exogenously imposed large portfolio share of housing. Hence, young families hold suboptimal portfolios by assumption, which they gradually shift toward more desirable, less-housing-intensive, and less-leveraged portfolios as they age and accumulate wealth.

$\underline{8}$ Piazzesi, Schneider, and Tuzel (2007) study asset pricing in a model that includes housing. They use a representativeagent general equilibrium framework with complete financial markets, frictionless markets for owner-occupied and rental housing, and no borrowing constraints. Thus, all agents hold the same portfolio shares at a given time and there are no life cycle considerations. The representative agent never holds a suboptimal portfolio while consuming housing and nonhousing goods and services because it is costless to shift between rental and owner-occupied housing and to vary the share of housing and nonhousing consumption.

9 One possible explanation for greater mortgage borrowing by older homeowners is that the age distribution of those 62 years of age and older has changed. However, the share of those 60 to 74 years of age (the "young old") in the population 60 years of age and older has been increasing rapidly only since 2000; therefore, this explanation cannot explain why the increase began in the early 1990 s. A second potential explanation is that older homeowners increasingly have used the equity in their homes to collateralize borrowing for other purposes. This appears to be an important factor that may have combined with a rising share of young old families and rising house values in the 2000 s.

10 See Emmons and Noeth (2013) for a detailed discussion of mortgage borrowing between 2000 and 2012 across age groups and in birth-year cohorts.

11 In other unpublished work that attempts to reconcile data from the SCF with aggregate financial data in the Federal Reserve's flow of funds accounts, we found evidence suggesting the LTV ratios reported in the SCF may be lower and less volatile than actual ratios, on average. Possible misreporting of various items in the survey is not a major concern in this article unless there are systematic biases across different age, education, or racial and ethnic groups, for which we have no evidence.

12 See Paoli (2012). A private estimate of the share of homeowners younger than 40 years of age with mortgage debt that exceeds the market value of the house securing it was 48 percent in the second quarter of 2012, compared with a rate of about 31 percent among all homeowners with mortgage debt.

$\underline{13}$ The only notable exception to this general rule is that middle-aged and older families with less than a high school education appear, along some dimensions, to be more like highly educated young families than more highly educated families closer to their own age. One way to think about this is that, on average, almost all young families appear "poor" in the sense of being financially constrained, while only those families with less than a high school education appear "poor," on average, when they are older than 40 years of age.

14 The ranges for middle-aged and older nonminority families of all educational levels in 2007 were 54 to 87 percent and 75 to 90 percent, respectively. The ranges of minority homeownership rates for middle-aged and older families were 50 to 77 percent and 50 to 80 percent, respectively. 


\section{Emmons and Noeth}

15 Sample sizes are as small as 27 observations for families headed by minority college graduates younger than 40 years of age in 1989. Thus, sampling variability is an important consideration when interpreting these results. In general, smaller sample sizes are associated with more irregular time-series patterns in the figures.

\section{REFERENCES}

Bricker, Jesse; Kennickell, Arthur B.; Moore, Kevin B. and Sabelhaus, John. "Changes in U.S. Family Finances from 2007 to 2010: Evidence from the Survey of Consumer Finances." Federal Reserve Bulletin, June 2012, 98(2), pp. 1-80; www.federalreserve.gov/pubs/bulletin/2012/pdf/scf12.pdf.

Emmons, William R. and Noeth, Bryan J. "Household Financial Stability: Who Suffered the Most from the Crisis?" Federal Reserve Bank of St. Louis Regional Economist, July 2012a, 20(4), pp. 11-17; www.stlouisfed.org/publications/re/articles/?id=2254.

Emmons, William and Noeth, Bryan. "Why Did Young Households Lose So Much Wealth During the Crisis? The Role of Homeownership." Household Financial Stability initiative, unpublished manuscript, Federal Reserve Bank of St. Louis, 2012b.

Emmons, William R. and Noeth, Bryan J. "Mortgage Debt Through the Ages." Federal Reserve Bank of St. Louis Regional Economist, January 2013, 21(1), online only; www.stlouisfed.org/publications/re/.

Flavin, Marjorie and Yamashita, Takashi. "Owner-Occupied Housing and the Composition of the Household Portfolio." American Economic Review, March 2002, 92(1), pp. 345-62.

Montalto, Catherine Phillips and Sung, Jaimie. "Multiple Imputation in the 1992 Survey of Consumer Finances." Financial Counseling and Planning, 1996, 7, pp. 133-41.

Paoli, Alison. "Negative Equity Falls in Q2; Half of Borrowers Under 40 Underwater." Zillow blog, August 22, 2012; www.zillow.com/blog/2012-08-22/negative-equity-falls-in-q2-half-of-borrowers-under-40-underwater/.

Piazzesi, Monika; Schneider, Martin and Tuzel, Selale. "Housing, Consumption and Asset Pricing." Journal of Financial Economics, March 2007, 83(3), pp. 531-69.

U.S. Census Bureau. “Housing Vacancies and Homeownership”; www.census.gov/housing/hvs/data/histtabs.html. 